\title{
Lexis
}

Journal in English Lexicology

Book reviews | 2006

\section{Lynda MUGGLESTONE, The Oxford History of English}

Oxford University Press, 2006, 485 pages

\section{Graham Ranger}

\section{OpenEdition}

\section{Journals}

\section{Electronic version}

URL: http://journals.openedition.org/lexis/1895

DOI: $10.4000 /$ lexis. 1895

ISSN: 1951-6215

\section{Publisher}

Université Jean Moulin - Lyon 3

\section{Electronic reference}

Graham Ranger, «Lynda mugglestone, The Oxford History of English», Lexis [Online], Book reviews, Online since 01 December 2006, connection on 24 September 2020. URL : http://journals.openedition.org/ lexis/1895; DOI : https://doi.org/10.4000/lexis.1895

This text was automatically generated on 24 September 2020.

\section{(c) $($ ) $(9)$}

Lexis is licensed under a Creative Commons Attribution-NonCommercial-NoDerivatives 4.0 International License. 


\title{
Lynda MUGGLESTONE, The Oxford History of English
}

Oxford University Press, 2006, 485 pages

\author{
Graham Ranger
}

\section{REFERENCES}

Lynda Mugglestone

The Oxford History of English. Oxford University Press, 2006. ISBN: 978-0199544394, Prix :

$\$ 23,485$ pages

1 The Oxford History of English is a handsome, finely presented volume running to nearly 500 pages, including a general introduction, fourteen thematic chapters, some forty pages of bibliographical references and a well-compiled index. Additionally the book contains a key to phonetic symbols, an IPA Mouth Diagram (that is, the standard parallelogram representing the positions of articulation for the vowels) and a full chronology of English, combining socio-political, historical and linguistic landmarks.

2 Mugglestone's introduction opens with the following quote: "How can there be a true History, when we see no Man living is able to write truly the History of the last Week?"1 This sets the tone for The Oxford History of English which aims at "the construction of 'a history' rather than 'the history', recognizing that many [...] pathways could be navigated through the past-and present-of the English language" (2). The emphasis throughout is placed on the heterogeneity of English and on the nature of the transitions which have marked its history. In this respect The Oxford History of English is very different from many standard histories of the language which tend, Mugglestone suggests, a) to focus on one variety of English (marginalising or trivialising others in the process) and b) to caricature the transitional nature of historical change with a series of sudden passages from one stage to the next. The Oxford History of English is therefore to some degree a counter-history of English, a corrective to what it sees as an excessive oversimplification in the field. It aims nonetheless to provide "an accessible 
and discursive text in which primary material is glossed where necessary or (for earlier periods) translated in full" (6).

The fourteen chapters offer a broadly chronological progression through the history of the language, from the Proto-Indo-European origins through to the twenty-first century. There is some degree of overlap between chapters, understandably enough given the theoretical standpoint from which the book is written and the fact that the fourteen chapters are written by fourteen different contributors, each a specialist in their field. In the remainder of this review I will briefly summarise the content of these chapters before offering my own critical assessment of The Oxford History of English.

Chapter 1, "Preliminaries: Before English", by Terry Hoad, charts the prehistory of English, from Proto-Indo-European to Germanic and then from Proto-Germanic to East, North and West Germanic. Hoad begins with an illuminating parallel between the linguistic aspects of 17th century migrations towards America and the migrations of Germanic speaking peoples towards the British Isles some twelve centuries earlier. He then goes on to present a number of phonetic, grammatical and lexical differences between Proto-Indo-European and Germanic, including Grimm's Law, naturally enough, and then between the different branches of Germanic itself. Hoad integrates recent research that questions the notion of a passage from West Germanic to AngloFrisian and thence to Old English and old Frisian, suggesting that "the similarities between Old English, Old Frisian and Old Saxon are perhaps better seen as the result of parallel developments in a complex and changing social and linguistic situation" (27). There is also interesting discussion on dating borrowings from Celtic into Old English and from Latin into Germanic.

Chapter 2, "Beginnings and Transitions: Old English", by Susan Irvine is organised around what Irvine terms "five historical watersheds" in the development of old English. The first is the "migration myth" (34) vehicled by Bede's classic account of the Germanic invasions, which places different migrating peoples firmly in different parts of the British Isles. The nature of the link between dialect and locality is often very difficult to establish, however, as Irvine shows with a number of fine textual studies. The second historical landmark is that of the conversion to Christianity and the subsequent abandonment of runic script in favour of the Roman alphabet. Irvine then considers the reign of Alfred (871-899 A.D.) and the production during this period of manuscripts in the vernacular before looking at how the Benedictine Reform stimulated the use of the vernacular for didactic purposes and encouraged a certain regularisation of written English based on the school of Winchester. The last of the five watersheds is, of course, the Norman Conquest. Irvine shows how this precipitated changes which were in some cases already under way without necessarily transforming the language quite as thoroughly as some older accounts would have it: "The transition from old to Middle English is only the last in a series of transitions which the old English language underwent over its seven centuries of existence" (58). Irvine's chapter is illustrated throughout with precise discussion of original and revealing examples from old English texts.

Chapter 3, by Matthew Townend, is entitled "Contacts and Conflicts: Latin, Norse, and French". In it, Townend addresses the fact that English in England has often been just one language among others: "To write linguistic history by looking only at English would give an entirely false impression of linguistic activity in England; it would be like writing social history by looking at only one class, or only one gender" (61). Townend's 
aim is "to introduce the complex multilingualism - and, therefore, multiculturalism-of medieval England" (61). Regarding post-Conquest England, Townend tells us "there is little value in older accounts which depict two distinct speech-communities, English and French, running on non-convergent parallel lines for a number of centuries" (67). A number of interesting distinctions help the discussion, in particular those between individual and societal bilingualism (70) or between the concepts of "borrowing" and" imposition". The former is the adoption of a term from one language into another while the latter involves the imposition of a non-native term into a language other than the speaker's. This difference is particularly important in understanding the phonological behaviour of the new terms. The chapter closes with careful analysis of old and Middle English texts illustrating the scale of language contact, particularly in the form of loan-words.

Chapter 4, "Middle English-Dialects and Diversity", by Marilyn Corrie, looks at what Corrie terms the "anxiety" of the period about how to represent written English in times of dialectal diversity and in the absence of a written norm. This anxiety is illustrated first with an extract from the Ormulum in which Orm-renowned for his idiosyncratic but, it is supposed, phonetically justifiable, spelling system-requires future scribes to copy things just as he has chosen to write them. Corrie then analyses the differences between two versions of an extract from the Ancrene Wisse, made by scribes of different dialectal backgrounds, before discussing the mutual intelligibility or otherwise of North and South dialects of Middle English. In 1362 the Statute of Pleading allowed for court proceedings to be conducted in English, thereby legitimising the vernacular. 1350 is the date at which the Linguistic Atlas of Late Mediaeval English begins and Corrie uses this as her source for the different forms of Middle English words for 'she', ranging from $s(c)(h)_{0}$ in the North-West to hy(e) and hi(j) in the South-East for example. A section is dedicated to London English as something of a linguistic melting pot whose diversity Chaucer drew upon considerably. Finally, Corrie draws upon other research to suggest that traditional views of Chancery English as providing the standard to be copied are open to criticism: "the homogeneity which has been claimed for the English of the Chancery is, in fact, a myth" (112) she writes, following Benskin. ${ }^{2}$ She does however remark upon "the relative stability of written English between the fifteenth and the twenty-first centuries-and the great pace of its development between Old English and the end of Middle English" (113). The anxiety that opened the chapter appears to be somewhat calmed by Henry V's "recognition that the English language could be viewed as a defining feature of the English people" (114).

Chapter 5, "From Middle to Early Modern English", by Jeremy J. Smith, begins by qualifying the traditional distinction between "internal" approaches to the history of English (changes in the forms of the language) and "external" approaches to the same (changes in function). Form and function are inextricably linked and the changes in the period Smith presents are linked to the "elaboration" (122) of English as a prestige language. The chapter looks firstly at the enrichment of the vernacular lexicon both with inkhorn terms and the borrowing of terms from French as a way of marking social differences at the very time that this language was disappearing from the British Isles. Changes in grammar are then discussed, in particular the differences between old Scots and Southern English and differences in syntax reflecting different registers, extracts from the Paston letters providing good illustrations of "low style". The spelling conventions of English in the period under study display a certain standardization but this is far from a straightforward aping of the Chancery English model, Smith claims, as 
he downplays the role of government in standardizing the language, arguing that, as English came to function nationally, so a "colourless written English" evolved to facilitate communication on a national level. The increase in the population of London over the fourteenth century led to dialectal differences within the city. Vocalic hyperadaptation by newly arrived speakers of Midlands English imitating the London standard, says Smith, may have been an important factor in the Great Vowel Shift. The chapter is illustrated with thoroughly discussed extracts from period texts of different genres.

Chapter 6, "Restructuring Renaissance English", by April McMahon is more abstract than the previous chapters. After some introductory remarks on lexical and morphosyntactic changes the chapter moves on to phonology and more particularly to the Great Vowel Shift. Interesting arguments are made for the use in research of corpora and period texts by orthoepists such as $\mathrm{Hart}^{3}$ before McMahon presents us with typical "textbook views of the Great Vowel Shift". The traditional exposition of the Shift may tend to idealize the data, to make the overall pattern look neater, McMahon suggests: "Are we [...] including or excluding certain changes purely because the overall outline then looks more uniform and easier to handle than the sum of its more realistic parts?" (159) In a section entitled "What, if anything was the Great Vowel Shift"4 McMahon gives us the opposing views of Lass, on the one hand, and Stockwell and Minkova, on the other. ${ }^{5}$ Lass argues that "seeing the GVS as a real, single, and unitary phenomenon is both justified and helpful in interpreting the history of English" (161) while for Stockwell and Minkova it is "counter-productive to reify a series of independent changes as a single object, since this focuses the minds of linguists on accounting for an idealized change which, they contend, never really happened." (161) The arguments presented are often complex and McMahon indeed warns us at one point, "readers of a nervous disposition may be better advised to skip [the next section]" (167)! She concludes pragmatically that "[p]erhaps, in the end, the real argument comes down to what different scholars are willing to accept, and how high or low they set their thresholds for realism as opposed to idealism and abstraction" (175).

Chapter 7, "Mapping Change in Tudor English", by Terttu Nevalainen, focusses mainly on the disappearance of the third-person -eth ending and the use of the do auxiliary in Tudor English, studied through the often statistical evidence provided by corpora. Nevalainen firstly presents the notion of genre in corpora, showing, interestingly, how the expression provided that appears initially in fifteenth-century statutory texts before spreading in the seventeenth-century to other less formal modes of discourse. The rise of the Northern third-person singular -(e)s ending, to the detriment of Southern -eth, is charted through careful corpus analysis, enabling Nevalainen to conclude that "[it] is probably the full and uncontracted -es form which reached London in the late fifteenth century. Like some other northern features which are also attested in London English at this time, it failed to gain wider acceptance. However, the second time-(e)s surfaced in the capital, in the sixteenth century, it involved vowel contraction [and] found its way into the supra-local variety used by the literate people of the time. The traditional southern form -eth had meanwhile gained a firm position in formal contexts as, for instance, in liturgical speech, but it was also retained in many regional dialects" (193). The same meticulous approach to corpus data is adopted in Nevalainen's studies of you and thou and, at much greater length, of do. Her attention to differences in usage according to the gender of the speaker (or writer) is particularly interesting. As she writes in conclusion "[1]anguage change does not happen overnight or spread 
uniformly throughout the country across the whole social spectrum [...] even the most familiar aspects of the English language are the result of quite intricate processes of change." (208).

11 Chapter 8, "The Babel of Renaissance English", by Paula Blank "aims to remedy the insularity of studies that focus on the rise of a standard, national language in late Renaissance England by reconstructing what Renaissance writers deemed the 'Babel' of early modern English" (212). Blank studies this Babel, in terms of both regional and class differences. Western English is typically portrayed as "the most foreign of English dialects [...] from the standpoint of an elite social class" (215) and is generally associated with uneducated rustics in contemporary representations. The specific features of the northern dialect are more fully documented in written Renaissance English and, Blank suggests, the dialect was itself more generally accepted, thanks partly to its representation in Spenser's Shepheardes Calendar: "In the Renaissance, northern English was [...] regarded as a remote region of the vernacular but also, at times, as the most authentic, the most 'native' of dialects" (221). Blank presents the inkhorn terms of the Renaissance as a way of marking social advancement through language and, at the opposite end of the social scale, looks at the use of underclass English or "cant", the slang of the criminal classes. She also notes the emergence of a certain literary archaism attached to poetic discourse. Interestingly, the earliest English dictionaries dating back to this period do not aim to give a comprehensive picture of the language but "were exactly like the foreign language dictionaries that preceded them [...providing] translations of words which were largely foreign to native speakers into an English that all could understand" (231) so that "what is at stake in early modern lexicography is, above all, access to knowledge-the 'opening up' of signification to the uninitiated, unsuspecting, or unschooled." (233)

"English at the Onset of the Normative Tradition" is the title of Chapter 9, by Ingrid Tieken-Boon van Ostade. She begins by evoking Dryden's call for an Academy of English and the development of dictionaries and grammars during the same period. Her aim, however, is to consider the various forms of variation in language which continued to exist, evidence of which is often to be found in private writings. In the course of the chapter Tieken-Boon van Ostade analyses a number of examples taken from texts produced by people of social and geographical mobility. She draws upon social network analysis and in particular looks at how the type of network influences the language used in letters. This type of analysis enables us to discover dual standards in the spelling system: "a public one, as found in printed documents [...] and a private one, found in letters. This dual spelling standard was even recognized by the schoolmasters. And, indeed, it was very widespread." (255) There are, by the same token, public and private grammars, notes Tieken-Boon van Ostade, giving examples of each, as well as of the way in which the codification of grammar was affecting the language. The chapter aims to demonstrate that "contrary to the stereotypes of this period which often prevail in histories of the language, writers were not yet as constrained by normative writings [... Grammars...] primarily served the function of making accessible new linguistic norms to those who sought social advancement, rather than controlling the language per se. This important insight comes from the recognition of the significance of the language of private letters. No history of modern English will be complete unless the language of letters is taken into account as well." (270) 
Chapter 10, "English in the Nineteenth Century", by Lynda Mugglestone begins by drawing attention to the visible changes in the language as new words appear for new concepts, emblematic examples being Macadam, cab, omnibus, bicycle, velocipede. The quantity of linguistic material available increases exponentially in the Victorian era wih the advent of steam-powered printing presses. Letter-sending follows suit: Mugglestone notes a remarkable increase from 75 million letters sent in 1839 to 347 million just ten years later. She criticises what she calls the "myths of stasis": "Given the insistence by historians on the nineteenth century as a period of particularly dramatic shift, it can seem ironic that, in histories of the language, it is the absence of significant linguistic change which instead comes to the fore" (278). The language is a lot less fixed than traditional accounts claim, suggests Mugglestone, providing examples of variation in spelling and grammar, as well as the criticism these variations received in normative grammars. Two examples drawn from transcribed statements to the Select Committee of the House of Commons Enquiry into War in the Crimea are of particular interest in that they provide us with some insight into the oral syntax of the nineteenth century. Mugglestone goes on to consider variations of pronunciation of the period, looking in some detail first at attitudes to $h$-dropping and then at regional and class variations, with fascinating quotes from working-class sources which "challenge the patronizing stereotypes which could surround the lower classes of the nineteenth century when seen from the standpoint of those higher in the social order" (296). The chapter ends on the "supreme linguistic achievement" (297) of the first edition of the OED (1884-1828) "a compelling picture of the idiomatic vigour of nineteenth-century English [...taking] us far closer to the colloquial texture of nineteenth-century usage, confronting us once again with a dynamism which is impossible to ignore" (301).

Chapter 11, "Modern Regional English in the British Isles", by Clive Upton, opens with a subsection entitled "The Beginnings of Dialectology". Here Upton looks at the preparation of the English Dialect Dictionary and the English Dialect Grammar (published in 1898-1905) as the high point in a movement which saw itself as noting down the dialectal and regional differences in the British Isles before they disappeared for ever. Dialect studies nonetheless resurfaced after the Second World War in particular with the Survey of English Dialects (SED). It is from this survey that Upton takes a map using isoglosses to chart the way in which $<\mathrm{u}>$ in the word thunder is pronounced according to region. Upton rejects the idea of "tightly-drawn dialect boundaries [as] illusory" (311), focussing instead on a number of regional features and their distributions and implications. These features are dealt with in separate sections devoted to pronunciation (invariant $u$, short or long $a$, retroflex $r$ ), vocabulary (with notable differences in particular between Scots and Irish relative to standard Southern English) and grammar (Upton discusses pronouns as "a very fertile area for variation generally"). The notion that linguistic variation may be seen as "a badge of regional affiliation" (325) is an interesting one, which might have been pursued further, I felt. Additionally, Upton's repetition throughout that "non-standard is not sub-standard" (313), while justified, of course, is perhaps not as necessary in the context of the present volume as his insistence would seem to suggest.

15 Chapter 12 by Richard W. Bailey is entitled "English Among the Languages". It parallels, to some extent, the earlier chapter by Townend, looking at "interactions between English and other languages, focusing on the period between the later Renaissance and modern English" (334). Again the author writes against "[0]ld-fashioned language 
histories [which] have often endeavoured to look at a 'national' language as if it were a single (and triumphant) result of some Darwinian process of selection" (335). Bailey draws parallels between multilingual communities of the past and the present, quoting from certain fourteenth and fifteenth-century texts which happily mix Latin, French and English. He also amusingly notes that exotic English borrowings in the early modern period (chocolate, maize, potato, tomato) are often in fact borrowed from Spanish or Portuguese, much as the riches of the new world were stolen not from their original possessors but from the other European nations that had previously amassed them. It is in the eighteenth century, says Bailey, that the idea of the destiny of English as a world language appears. Borrowing increases with the decrease of multilingualism, for commercial purposes in the eighteenth and nineteenth century and for the purposes of science in the nineteenth. Bailey goes on to describe the fascination of nineteenthcentury commentators with the otherness of the English-based creoles before moving on to "English International, Ltd." (353) in the twentieth. Interestingly, borrowings from other languages appear to have diminished in the twentieth century but codeswitching within texts has increased. The chapter concludes with a flourish, quoting the curriculum vitae of a Hong Kong actress which mixes Chinese and English in a way strikingly similar to that in which the late medieval texts of the beginning of the chapter mixed English, French and Latin.

Chapter 13, "English World-Wide in the Twentieth Century", by Tom McArthur, describes how, over the last century, English has evolved into a global language. An introductory subsection, "English, Englishes, English Languages", looks at the development in the study of often hybrid varieties of English outside the British Isles and North America, from the 1970s on. McArthur then goes on to look at the gradual erosion of the prestige of Received Standard English over the century, with competition from the US and a certain democratisation within the British Isles from the 1960s on. The twentieth-century success of English as a world language is attributed to three sets of events: the outcome of two world wars in which English-speaking nations emerged victorious; the outcome of the Cold War and the way in which the former Eastern bloc nations had come to consider English as the language of freedom; globalization and the role of English as the language of international commerce and the world's media (369-370). This process has been accompanied by a shift in prestige and importance from UK to US English. Another factor in the success of English, suggests McArthur, is the lack of competition from other languages, often for socio-economic reasons, and the place of English as the language of the global West. A place which relates to the "unarguable utility of English [...] access to [which] comes (perilously?) close to a human right" (390). McArthur's chapter is stimulating reading, if a little hard to follow at times, undoubtedly because of its ambitious scope.

The fourteenth and final chapter in the volume is "Into the Twenty-First Century" by David Crystal. Crystal first considers the long-term consequences of globalization and in particular the "steady growth in the number of New Englishes, and-within thesean increase in new functions, new forms, and new literatures" (396). The "errors" of usage in non standard Englishes "gradually take on the character of regional spoken standards" (396) Crystal affirms, citing the case of the greeting "Welcome in Egypt". New Englishes produce New Literatures as speakers acquire linguistic confidence. In illustration of this point, Crystal quotes a number of sources, including the following remarkable extract from an account of a sumo contest in The Daily Yomiuri: "Wakonahana, facing one of the few rikishi smaller than himself, had little trouble with 
No. 6 maegashire Mainoumi, who could use none of his tricks agains the technicallysound sekiwake" (399). Linguistic terminology needs a word for "the state of a language which arises out of its status as a lingua franca in a community" (400) Crystal notes. Other areas in which English is evolving quickly are computing and the Internet. Crystal quotes a somewhat perplexing extract from an Internet chatroom which, he argues, would require us to revise our standard representations of conversational exchange. New words appear in new ways as spamming software attempts to circumvent spam filters by creating VI@GRA or pharmac ${ }^{\wedge} y$, for example (406). "We seem to be at a transitional point between two worlds" Crystal argues, an old and a new world where "non-standard regional usage is achieving a new presence and respectability within society, reminiscent of that found in Middle English (408). $\mathrm{He}$ concludes that "[A] new intellectual sociolinguistic climate is slowly but surely being formed, to which the present volume will no doubt made a significant contribution" (412).

18 All in all, The Oxford History of English is an original and thought-provoking account of the history of the language which challenges older more traditional views in many of the fields and periods it covers in the spirit of Crystal's The Stories of English. ${ }^{6}$ The essays are written by top specialists in their fields and each contains a page or two of precise indications for further reading should one wish to explore the issues in greater depth. More maps, diagrams and figures would sometimes have aided my own understanding of the issues, I feel, and would definitely not be out of place in such a well-presented volume. In so far as The Oxford History of English is in some ways a counter-history, written from a definitely postmodern and postcolonial perspective, it often presupposes a knowledge of standard histories which the non-specialist will not necessarily have. This makes it possibly less immediately accessible than Mugglestone's introductory chapter might lead us to believe. Such criticism is inevitable though, in a volume which aims to avoid intellectual facilities and to engage with the complexity of the issues involved originally and relevantly, in a way that, to my knowledge, few previous works have done.

\section{BIBLIOGRAPHY}

BENSKIN M., "Chancery Standard”, in KAY C., HOUGH C. \& WOTHERSPOON I. (eds.), New Perspectives on English Historical Linguistics: Selected Papers from 12 ICEHL, The Theory and History of Linguistic Science, 252, Amsterdam, John Benjamins, 2004: 1-40.

BRAGG M., The Adventure of English, London, Sceptre Press, 2004.

CRYSTAL D., The Stories of English, London, Allen Lane, 2004.

LASS R., "Vowel Shifts, great and otherwise: Remarks on Stockwell and Minkova”, in KASTOVSKY D. \& BAUER G. (eds), Luick Revisited. Tübingen: Gunter Narr Verlag, 1988: 395-410.

Stockwell R.P. \& MinKova D., “The English Vowel Shift: Problems of coherence and explanation”, in KASTOVSKY D. \& BAUER G. (eds.), Luick Revisited, Tübingen, Gunter Narr Verlag, 1988: 355-394. 


\section{NOTES}

1. T. Shadwell, The Squire of Alsatia (1688) quoted on p. 1.

2. In this Corrie refers to an article by M. Benskin, '"Chancery Standard"', in Kay C., Hough C. and Wotherspoon I. (eds.), 2004.

3. An Orthographie, Hart (1569). Reprinted in facsimile Menston, The Scolar Press, 1969.

4. The subheading, as McMahon reminds us, is in fact the title of a 1992 article by Roger Lass.

5. McMahon is referring to a long-running difference between these linguists as to how best to consider the Great Vowel Shift.

6. And in clear opposition to, say, M. Bragg's The Adventure of English (2004).

\section{AUTHORS}

\section{GRAHAM RANGER}

Graham Ranger, Department of English, Université d'Avignon et des Pays de Vaucluse, France. Graham Ranger works as a senior lecturer at the Université d'Avignon et des Pays de Vaucluse where he teaches English Linguistics and Translation. Although his work is mainly carried out within the field of formal enunciative linguistics, he also has a keen interest in the history of language and has taught a third-year class on the history of English for the last eight years. 